\title{
Reviews
}

\section{Enrique Alcaraz Varó y Brian Hughes. Diccionario de términos jurídicos Inglés- Español/Spanish-English. Barcelona: Ariel, 1992, XVII + 577 pp.}

Los que nos dedicamos al campo de la traducción jurídica en España hemos entrado en una etapa de cambios vertiginosos. Por una parte, la implantación de la nueva licenciatura en traducción e interpretación ha dado el espaldarazo definitivo al estudio del inglés jurídico dentro del Inglés para Fines Específicos (IFE); por otro lado, el Ministerio de Asuntos Exteriores deshoja la margarita sobre el examen de intérprete jurado, y puede que este año sea el último antes de la gran reforma prometida. Finalmente, la incorporación definitiva a la comunidad y el mercado europeo augura un intercambio masivo de textos y documentos entre España y otros países.

Es en este marco en el que debemos analizar la llegada de un nuevo diccionario, como instrumento indispensable para la tarea, llena de responsabilidad, del traductor. En el caso de la obra que nos ocupa, presentada por los doctores Alcaraz y Hughes, su aparición constituye una alegría, en primer lugar, para los traductores de textos legales. Hasta ahora, los diccionarios existentes han venido cumpliendo una función de glosario, pero poco más; las definiciones ofrecían equivalencias, pero con escasa o ninguna explicación sobre las distintas acepciones y casi ningún ejemplo.

El presente diccionario, concebido desde la práctica de la traducción, es ante todo generoso en sus planteamientos. Cada entrada recoge, además del equivalente castellano, un ejemplo del uso en inglés del término, seguido de un gran número de derivados y expresiones con sus consiguientes traducciones. Por ejemplo, la definición del verbo file incluye "cursar," “elevar," “instar," "formular," "archivar," “entablar" y "residenciar," pero a continuación encontraremos file a bill/petition in bankruptcy (declararse en quiebra, presentar la declaración judicial de quiebra), file a claim/complaint (elevar una queja o reclamación), file a suit/lawsuit (demandar, entablar un pleito), file a motion (cursar, elevar un recurso), file an objection (formular un reparo), etc.

Además de los abundantes sinónimos y referencias cruzadas, son frecuentes también las explicaciones; al hablársenos de joint se explica, además de su significado, las diferencias con common y concurrent, con el ejemplo del contraste entre joint tortfeasors, responsables conjuntos de un acto negligente que actúan mancomunadamente, $\mathbf{y}$ concurrent tort-feasors, corresponsables de forma individual. En este sentido, aflora el profundo conocimiento de los autores del mundo jurídico anglosajón, con numerosos elementos de derecho escocés y estadounidense.

También es interesante la inclusión de lo que se denomina "lenguaje paralelo," es decir, la aproximación por parte de la prensa al lenguaje jurídico, no estrictamente preciso 
terminológicamente hablando, pero de gran relevancia. Así, podemos destacar el contraste entre commence legal proceedings y sue: ambos se refieren a "demandar," aunque el primero es el término exacto y el segundo es la forma coloquial o periodística. También observamos la profunda sensibilidad de los autores hacia la evolución de los tiempos en la aparición de expresiones como "judicialización de la vida política" e "insumisión."

Sin embargo, la mayor aportación de este diccionario la constituye su carácter bilingüe real; de nuevo, una mirada a las obras existentes nos revela una segunda parte españolinglés concebida como mero apéndice, como sección de consulta rápida. En nuestro caso, la visión lingüística de los autores permite que la "segunda mitad del diccionario" sea una verdadera ayuda a la traducción inversa, tan complicada, pero sin embargo necesaria, ya que los mismos criterios de claridad y coherencia determinan una gran riqueza de ejemplos, expresiones y giros (en este sentido, la entrada de acción constituye una prueba de lo que debe hacer un diccionario para facilitar la traducción). Del mismo modo, se trata de una obra lo bastante clara y explicativa para que puede utilizarse desde el mundo anglosajón como forma de acceso al derecho español.

En resumen, se trata de una obra indispensable, no ya sólo para el traductor jurídico y todo miembro de la abogacía, sino para completar la visión del inglés empresarial de cualquier estudioso del IFE. Sin duda, la favorable acogida que ha tenido la primera edición hará que la labor de traducir ya no sea la misma después de esta obra.

\section{Miguel Ángel Campos Pardillos}

\section{James Joyce. "Anna Livia Plurabelle" (Finnegans Wake I.vIm). Ed. bilingüe de Francisco García Tortosa. Madrid: Cátedra, 1992, 181 pp.}

Cuando salen a la luz trabajos como el recientemente aparecido de García Tortosa sobre Finnegans Wake, uno no puede menos que alegrarse de ser universitario y académico, joyceano y lector, y de moverse además por aguas que le son harto familiares en su labor crítica. Pero muy por encima de todo ello, es cualquier amante de la lectura y de la cultura en general quien debe congratularse por la publicación de este trabajo que viene a acercar, con una ejecución que diría impecable, al cada vez menos impenetrable y desconocido James Joyce.

El trabajo que nos ocupa es en realidad dos obras bien diferenciadas y autónomas, con entidad propia, ambas de gran altura y valor académico. Sin entrar en detalles aún, éstas serían la "Introducción" y la "Traducción" propiamente dicha. El libro se divide en seis grandes apartados o capítulos, los cuatro primeros numerados y que forman parte de lo que se denomina la "Introducción": I. Joyce y Finnegans Wake; II. Finnegans Wake; III. Anna Livia; IV. La traducción de Anna Livia Plurabelle. Cada uno de ellos, a su vez, se divide en diversos apartados, ya sin titular. Les sigue la "Bibliografía" y la traducción en sí, que en edición bilingüe cierra el trabajo con el epígrafe "Anna Livia Plurabelle." Responsables de la traducción son García Tortosa, Navarrete Franco y Tejedor Cabrera, todos ellos integrantes de un activo grupo de investigación sobre Joyce de la Universidad de Sevilla. 
Quizás el trabajo encabezado por García Tortosa pudiera haberse presentado de manera ligeramente distinta: si bien el contenido queda constituido por dos bloques bien diferenciados - Bibliografía aparte-, como se decía más arriba, en la forma se podría haber marcado mejor esta distinción, agrupando, por un lado, lo que son los capítulos I, II y III, y por otro lado el que ahora es IV, "La traducción de Anna Livia Plurabelle," unido y antecediendo inmediatamente a la traducción de FW I.VIII como su "auténtica" y "única" introducción. Todo ello seguido, como un tercer bloque, por la Bibliografía. Pero sus razones habrán tenido García Tortosa y sus dos colaboradores para estructurar el trabajo como lo han hecho.

En lo que uno no tiene más remedio que discrepar de García Tortosa es cuando afirma, en el umbral de su sinopsis argumental de $F W$ I.vIII, que no hay que olvidar "que éste no es más que el prólogo de una traducción. .." (p. 97). Por el contrario, y como se viene tratando de decir desde el principio, los tres primeros capítulos del trabajo representan y suponen una monografía en toda regla sobre Joyce y Finnegans Wake, un estudio ameno, erudito y enriquecedor incluso para los que de alguna manera puedan estar más familiarizados no sólo con la biografía sino también, y sobre todo, con el quehacer de Joyce. Es un estudio monográfico sensible a su arte; conocedor reverente, precavido, de los flirteos y engaños, siempre fieles, de Joyce con la lengua.

La estructura y organización del trabajo es igualmente loable: las diferentes partes de las que consta se ordenan, siguiendo también una técnica joyceana en Finnegans Wake, de mayor a menor, de general a particular, con disciplina casi férrea y un desarrollo lógico, de acercamiento progresivo, como sucede cuando con una cámara de cine se va pasando de planos generales a primeros planos, a veces hasta de forma imperceptible.

El capítulo I de la "Introducción" - "Joyce y Finnegans Wake" - se divide en cinco partes bien diferenciadas, en las que García Tortosa pone de manifiesto su excelente conocimiento de los materiales que maneja, fundamentalmente la biografía de Joyce y su última obra Finnegans Wake: Dublín en las obras de Joyce, su biografía y su familia, y los avatares del autor después de 1939 hasta su muerte en 1941. Esta parte, sin querer ser un tratamiento exhaustivo de la biografía de Joyce y de cómo ésta se encuentra entretejida en sus obras de una u otra forma, se convierte, por el estilo y dominio de las fuentes, en más interesante y esclarecedora que muchas introducciones al uso o estudios monográficos.

De especial relieve es la tercera sección de este capítulo, sobre todo las páginas 28 a 37. En ellas se estudia con amena erudición la presencia de Lucía Anna Joyce en Finnegans Wake a través no sólo de Issy, sino también de la madre Anna Livia Plurabelle. Se menciona y se analiza el mito universal de la Cenicienta, conectándolo con las funciones y nombres de la hija real de Joyce y de la hija en la obra. De modo que, si hemos de creer a García Tortosa, "[e]n todo lo que antecede se encuentran las claves de no pocos enigmas en Finnegans Wake y mayormente ... la solución al laberinto por el que Joyce introdujo a su hija en la obra" (pp. 31-32).

El capítulo II titulado "Finnegans Wake" está dividido en dos apartados o secciones, la primera de la cual comienza, con muy buen criterio, con la balada de "Finnegan's," a la que sutilmente se hace ya referencia en la portada del trabajo. Como García Tortosa afirma, "Finnegans Wake debe su título y en parte el armazón estructural, que controla la 
fuerza centrífuga de la obra, a una balada popular, conocida como 'Finnegan's Wake"" (40).

En este primer apartado (pp. 40-63) el autor se sitúa, para analizarlos, en los presupuestos filosóficos de Giambattista Vico y Giordano Bruno de Nola, manteniendo que si bien el tema central de Finnegans Wake puede ser el de la circularidad de la existencia del hombre en la tierra (p. 42), el carácter cíclico ya aparece en todas y cada una de las obras anteriores de Joyce, incluido Exiliados. Pero, y esto es importante por lo más novedoso, "[l]a circularidad es una de las claves de Finnegans Wake, de eso no cabe duda, pero el final no tiene por qué llevar literalmente al principio, es más, planteado en estos términos, iría contra la idea viconiana de analogía, por la que los ciclos se repiten de modo analógico, no idéntico" (p. 47). García Tortosa termina este primer apartado haciendo una breve sinopsis argumental, que comenta y conecta con la Historia Universal como amalgama de todas las historias. Para él la esencia de Finnegans Wake radica en el "All in all" de Hamlet y Stephen, en "todo está en todo."

En la parte final del segundo capítulo, siguiendo esa progresión de la que se hablaba más arriba, e inmediatamente antes de entrar en lo que titula "Anna Livia," el autor reflexiona sobre la lengua de Finnegans Wake. Es el de la lengua en general un terreno que García Tortosa domina con facilidad, y como joyceano se siente especialmente cómodo tratándolo en esta ocasión, respaldado además por una prosa que no por reflexiva deja de ser clara y directa. Si el tabernero de Chapelizod puede representar a todos los hombres, "la lengua inglesa tendría que desempeñar la misma función: ser única y todas al mismo tiempo" (pp. 64-65).

Con el tercer capítulo se concluye, en mi opinión, lo que es una auténtica monografía de gran calidad sobre el "hecho Joyce," centrada en Finnegans Wake. Fraccionado en cinco apartados, lo más relevante se encuentra en los dos primeros, aunque hay que mencionar la sinopsis de I.VIII página por página (pp. 96-106) y una última sección, breve, referida a los posibles modelos en los que se inspiró Joyce para perfilar el personaje de Anna Livia, en especial Nora Barnacle (pp. 107-09).

En un primer momento García Tortosa trata de las diferentes versiones o textos en los que ha ido evolucionando I.viII, cómo se ha ido enriqueciendo la idea original, de modo que “el método de composición que Joyce emplea en 'Anna Livia Plurabelle,' y en Finnegans Wake, no difiere substancialmente del que emplea la abeja en la fabricación del panal" (p. 96). Reforzando el estudio realizado sobre el texto, y también la importancia de esta parte, su análisis del nombre de la protagonista - si se me permite la expresiónfemenina de la obra, y que da título al tercer capítulo del de García Tortosa, es, a pesar de su brevedad, agudo y esclarecedor incluso para los que ya se consideraban familiarizados con el tema: sucesivamente, Plurabelle (p. 90), Livia (pp. 90-93), y Anna (p. 93).

Como se ha venido diciendo de forma insistente, a partir de aquí comienza otra monografía, la traducción de $F W$ I.VIII propiamente dicha, que debía terminar, en mi opinión, con la Bibliografía cerrando todo el trabajo. El capítulo IV titulado "La traducción de "Anna Livia Plurabelle"” es realmente una auténtica introducción que queda separada, innecesariamente por la Bibliografía general del trabajo, de aquello a lo que natrualmente debía anteceder de forma inmediata. 
Sigue siendo García Tortosa el autor de esta introducción, que en un primer momento (pp. 110-123) presenta y compara cinco traducciones de un texto representativo, cual es $F W 215.31-216.05$, esto es, el final de I.VIII. Las traducciones son al inglés básico de C.K. Odgen; al francés de Samuel Beckett y otros; al italiano del propio Joyce; al francés de Lavergne; al gallego de Leopoldo R. L. Rodríguez; y finalmente al castellano de García Tortosa, Navarrete Franco y Tejedor Cabrera. Y también se comenta una traducción castellana del mismo texto realizada privadamente por Silvia-Santiesteban, y una al catalán de Sobré que corresponde a $F W$ 538.18-539.08. El capítulo termina en un tono más personal (pp. 123-26) relatando como surgió la idea de la traducción y cómo ésta se llevó a cabo.

Con el mismo escrúpulo y rigor que se ha utilizado hasta el momento, la traducción de "Anna Livia Plurabelle" está cuidada, mimada hasta el detalle. El texto de $F W$ I.VIII se presenta en el original y traducido al castellano, páginas pares e impares, respectivamente, de la edición de Cátedra, cuyo contenido se corresponde exactamente con cada página y línea del original. Si bien las líneas no se numeran - siguiendo el uso de las ediciones oficiales- sí ocurre así con las páginas del original. Con respecto a la labor realizada en la traducción, sólo se puede decir que, habiendo conocido de antemano fragmentos de ella, es encomiable y respeta el proceso seguido por Joyce en su creción, lo que la hace más válida y universal.

La Bibliografía se divide en cuatro partes; fuentes primarias; general; bibliografía citada en la Introducción; y Bibliografía usada en la Traducción: nueve apretadas y densas páginas de títulos de siempre y actualizadas, que son un instrumento precioso para cualquiera, neófito o veterano, que quiera moverse por las aguas joyceanas.

"Anna Livia Plurabelle" (Finnegans Wake I.VIII), edición bilingüe de Francisco García Tortosa, es un pequeño tesoro del que todo amante de la literatura, incluso del arte en general, debe congratularse. La pulcritud de su ejecución hace que la investigación y traducción literarias adquieran nuevos y mejores valores en nuestro país, y desde luego se consolide, de una vez para siempre en el ámbito internacional, el trabajo que en el campo joyceano se viene realizando.

J. Carnero González

Francisco Javier Torres Ribelles. Eternal Shadows: Symbolism in the Theatre of W. B. Yeats. Alicante: Publicaciones de la Universidad de Alicante, 1992, 122 pp.

Eternal Shadows: Symbolism in the Theatre of W. B. Yeats is a solid study of the ideas that led to the writing of Yeats's plays and the ideas articulated in the plays themselves. It has two leading virtues: it is a timely book, and it has achieved the difficult balance sought in all scholarly writing which aims to satisfy the needs of the general reader without skimping on its duty to cogency, clarity and rigour.

As Torres explains in the early pages, one of his aims in writing Eternal Shadows was his desire to counteract the general bias which has arisen from the traditional view of W. B. Yeats as primarily a poet. Though he naturally acknowledges the high quality of 
Yeats's poetry, Torres endeavours to foreground the significance of his achievement in the drama. The book thus contributes to recent efforts to rescue Yeats's dramatic works from the partial oblivion into which they have fallen.

After pointing out the advantages the stage had for Yeats and providing a general picture of the different influences he underwent, Eternal Shadows analyses the fundamental principles ruling his aesthetics. Thus, the second section of the book considers the effects upon Yeats's work of his staunch opposition to the conception of the world generated by the Industrial Revolution. Torres's exposition is based on the idea that Yeats's theories are a direct consequence of his rejection of the modern world. The extent to which Yeats's drama depends on the theories expounded here is shown in the aptly chosen references and quotation accompanying Torres's explanations. In the same section he analyses the contrast between Yeats's notions of matter, space and time, and their correlates in the paradigm of Newtonian science.

The role of art as an alternative to the real world and the function of the theatre as a means of transforming society link the second section to those which follow. In them, Torres examines the significance for Yeats's theories of notions such as "symbol," "universal memory," "racial memory" and "mask," among others. There are some useful pointers to Yeats's expression of nationalistic ideas through myth, and our attention is drawn particularly to the ways in which the writer's nationalism affects his theatre. This discussion is complemented by a consideration of Yeats's interpretation of Irish culture and an examination of the strong link which he believed existed between the primitiveness of rural Ireland and the ancient Greek world.

Eternal Shadows is coherently organized, with a structure designed to satisfy its dual aim of providing both critical commentary and expository information. Once the main lines of Yeats's thought have been clearly stated, the book goes on to analyse the main points of his stagecraft and the leading features of the world presented in his plays, and to show how both depend on the playwright's known intellectual positions. The book underlines the importance of determinism to an understanding of the development of Yeats's themes, especially as these develop in the plays. Torres is then able to link this to the progress of Yeats's thought in other relevant areas, such as his interpretation of the theory of übermensch, and to provide a convincing explanation for the playwright's disillusionment and subsequent pessimism in his late years. This chronological approach to the development of the theme of determinism, together with the orderly arrangement of the various sections, make for smooth reading and compensate for the scarcity of biographical information, though perhaps a chronological table could have been provided for readers whose acquaintance with Yeats is slight.

Critical studies of Yeats's theatre are not, of course, new but Eternal Shadows goes more deeply than most into the relationship between the bedrock of Yeats's thought and his dramatic works. This is the source of the book's clarity, which is something to be thankful for, given the complexity of Yeats's texts. Torres's emphasis on the current relevance of Yeats's writings for the theatre and his role in the development of twentiethcentury drama also deserve praise, though in view of the importance of the subject one could have wished for a somewhat more detailed examination of the relation between Yeats's drama and that of such later Irish dramatists as O'Casey and Beckett. 
In any event, Eternal Shadows is a useful book, which should prove particularly helpful both to scholars and to students approching Yeats's theatre for the first time. Javier Torres not only manages, as Professor Anthony Roche ironically put it, "to talk on that most unfashionable and apparently contradictory of themes: W. B. Yeats as a man of the theatre"; he manages to do so with lucidity and insight.

Brian Hughes

\section{Gordon McMullan and Jonathan Hope, eds. The Politics of Tragicomedy: Shakespeare and After. London: Routledge, 1992, 212 págs.}

The Politics of Tragicomedy: Shakespeare and After is a collection of essays originally delivered as lectures at the meeting held at Wadham College in June of 1988 under the title of The Politics of Drama, 1610-1650. In its Preface and Introduction, the editors describe the purpose of this volume together with the criteria according to which the essays have been selected. The possibilities of characterizing tragicomedy not as a burlesque mixture of tragic/comic components, but rather as a self-defined genre, is the major concern leading G. McMullan and J. Hope to the publication of this Politics of Tragicomedy, where two fundamental objectives are accomplished. On the one hand, to gather together and make use of diverse standpoints regarding Renaissance politics and, on the other, to invite major professors and experts on this period to confer tragicomedy the literary status it deserves. Such an achievement will yield new, stimulating readings of the English drama written in the period between Shakespeare's last creative years and the creation of the Commonwealth. The term tragicomedy itself is thus subject to analysis, this volume covering all its established definitions, as well as the authorship of the model of tragicomedy unreliably attributed to John Fletcher.

All the essays collected share a common concern with political evolution as reflected in seventeenth-century theatre, looking for the key elements of political life between 1610 and 1650 in both the historical and social contexts and the role played by women in plays and audiences. The choice of these dates is by no means arbitrary: on the one hand, it obeys the editors' wish to study those Elizabethan strategies of drama distinct from Shakespeare's-thus reacting against New Historicism and its ineluctable dependence on his genius; on the other, it rescues all dramatic work yielded between 1642 and 1650, so far forgotten mostly due to the closure of theatres during that period. The aforesaid influence of social and historical contexts upon political evolution during the first half of the seventeenth century may be clearly observed in Lois Potter's and Martin Butler's essays. In "Topicality or Politics? The Two Noble Kinsmen, 1613-34," Potter examines the major topics of this play through a deep historical analysis and emphasizes the influence of social context when determining the political significance of The Two Noble Kinsmen. In his "Late Jonson," Butler focuses upon the last stages of Jonson's work -especially The New Inn- and shows how it reflects the parliamentary language of its time, and how the different themes handled lead this play to an ever-growing politization similar to that of the society which surrounded its author. 
Kathleen McLuskie's, Sophie Tomlinson's and Walter Cohen's essays study, from different standpoints, the role of women in the plays written between 1610 and 1650 . McLuskie and Tomlinson, in "“A Maidenhead, Amintor, at my Yeares': Chastity and tragicomedy in the Fletcher Plays" and "She That Plays the King: Henrietta Maria and the Threat of the Actress in Caroline Culture" respectively, coincide in their interest in studying in depth the role of women in audiences in Jacobean drama and its influence upon the progressive, privileged treatment of gender. Tomlinson, on the other hand, explores the concept of actress set forth in Caroline culture, according to which she analyses different plays-especially William Cartwright's The Lady Errant. Finally, Cohen's approach sets up a parallel between the social standard of women posited by the tragicomedies of this period and that of the working class in the literature of the Industrial Revolution: the mediating essence of the female character, which makes it easier for her lover to achieve political, monarchic power, is taken up again by the nineteenth-century working-man, whose co-ocurrence in the novel is unavoidable in order to achieve the hegemony of capital in England.

We will mention the essays by David Norbrook, Erica Sheen and Margot Heinemann all together, since, although they still share that common concern with the influence of social and political contexts, they also show certain special features which connect them to each other. Norbrook and Sheen contribute political readings of The Tempest and Cymbaline respectively. In “"What Cares These Roares for the Name of King?': Language and Utopia in The Tempest," Norbrook traces the dominant political voices of the play, from Guicciardini to Montaigne, thus advocating a rather Utopian reading of the The Tempest. In "“The Agent for His Master': Political Service and Professional Liberty in Cymbeline," Sheen argues that, in spite of the political conservatism traditionally associated with this play, Shakespeare makes his case against the absolutism of his age; furthermore, including Cymbeline in a general revolutionary frame, Sheen demystifies the common idea that Shakespeare accepted the cultural tenets of his age too readily. Heinemann's essay, on the other hand, seeks to unveil the social rootedness inherent in the tragicomedy of the first half of the seventeenth century, as well as widening Norbrook's concept of Utopia. The dénouements of these plays are, he argues, revealing enough. While popular theatre-Heinemann's major concern-have harsh, realistic endings, minority theatre conceals them behind Utopia in order to safeguard the reputation of social institutions and the hierarchical establishment.

Finally, we must note that although all the essays are interesting for their analysis of social, political and gender relationships of the seventeenth-century tragicomedy, Tomlinson's, Cohen's and Norbrook's are, we think, the most outstanding ones, especially due to both the originality of their approaches and the clarity of their expositions. 
Cándido Pérez Gállego. Literatura norteamericana: una visión crítica. Madrid: Palas Atenea, 1992, 467 págs.

A quien conozca ya la extensa obra de Cándido Pérez Gállego, el libro que reseñamos aquí le remitirá casi inmediatamente a alguna otra obra de su autor, en especial a su casi homónima Historia de la literatura norteamericana. Muchas de las cuestiones y sugerencias que hace pocos años afloraban en esta última son retomadas y remodeladas hoy en esta visión crítica. De hecho, tanto por los contenidos que cubren ambas como por su común organización, bien podemos entender que hoy tenemos entre manos una extensión de aquella Historia.

El propósito inicial del autor nos parece, en un principio, tan encomiable como inalcanzable: construir con más o menos detalle una historia de la literatura norteamericana (aunque el término más adecuado para este estudio sería estadounidense), desde finales del siglo XVI hasta la narrativa posmoderna de nuestros cercanos años ochenta, es sin duda tarea de toda una vida - hacerlo en menos de 500 páginas es ya un sueño de alquimistas - Es inevitable pensar que desde el principio vayan a quedar fuera de la obra innumerables cuestiones y detalles históricos, subtópicos literarios y consideraciones acerca de la construcción formal de la literatura estadounidense. Pues bien, y a pesar de todo, de ninguna manera debe entenderse que este libro carece de una perspectiva humanística definida; antes bien, ya desde las primeras páginas nos advierte el autor que el lector va a encontrar entre las páginas de esta Literatura norteamericana una muy personal lectura de la tradición literaria de los Estados Unidos. Quien lea esta obra no debe hacerlo, pues, tratando de hallar clasificaciones exhaustivas, ni tampoco organizaciones cronológicas de la historia literaria de aquel país; ni mucho menos un análisis o enfoque particularizado que deje de lado cualquier tipo de consideraciones pertinentes en el ámbito crítico-literario. Lo que el lector va a descubrir a lo largo de toda la obra es el fruto de largos años de lecturas y análisis, de revelaciones trabajadas a través de las experiencias docente e investigadora. Esta Literatura norteamericana es, ante todo, un compendio de ideas y sugerencias acerca de la literatura norteamericana maduradas con el paso del tiempo; y es, sobre todo, una exposición de relaciones entre textos, una muestra de algunas constantes temáticas y caracterológicas que, de una u otra manera, cruzan la literatura de los Estados Unidos como un eje unitario. Si bien es notorio que el interés de su autor radica esencialmente en la figura del héroe tal y como esta se va construyendo y conformando en las distintas épocas y los distintos autores de la tradición literaria norteamericana, es igualmente cierto que a este interés particular corren paralelas una visión de conjunto de las obras analizadas con mayor detalle y una constante referencia a la influencia de los lugares en que los distintos autores vivieron y estudiaron.

Precisamente por lo inmediatamente anterior podríamos, si fuese necesario, alojar esta Literatura norteamericana dentro de los estudios literarios de marcado corte psicológico, en el que la atención se dirige permanentemente a las diferentes formas en que la construcción caracterológica de los personajes, especialmente la de los héroes, refleja el complejo cultural de la sociedad norteamericana en su evolución.

De cualquier forma, esta Literatura norteamericana presenta algunas variaciones e innovaciones con respecto a otras obras anteriores de su autor. Uno de sus aciertos más 
notables, y que se echa de menos en libros de esta especie con mayor frecuencia de lo que sería deseable, consiste en ofrecer, paralelamente al estudio de la literatura norteamericana, un capítulo sobre la teoría y crítica literarias nacidas y desarrolladas en el seno de aquélla. De esta manera, Cándido Pérez Gállego nos ofrece en las últimas páginas de su obra un poético conjunto de reflexiones ceñidas a los principales teóricos de la literatura de nuestro siglo, grupo que incluye pensadores tan variados como Francis $O$. Mathiessen, Murray Krieger, Harold Bloom y Harry Levin.

En estas últimas líneas quisiéramos hacer algunas precisiones que aluden a la construcción general de la obra. En primer lugar, destacaremos la desigualdad en el espacio dedicado a cada autor. Es obvio que no todas las figuras de la literatura norteamericana han brillado con la misma intensidad; pero incluso entre las que to han hecho con pareja fuerza la distribución y profundidad de los análisis muestran notables desequilibrios. Las inevitables preferencias llevan al autor a dedicar un esfuerzo, espacio y minuciosidad mayores, entre otros, a Melville, Hawthorne, Thoreau, Hemingway, Updike y Bellow, en detrimento, por ejemplo, de James, Steinbeck, Faulkner, Kerouac, Ashbery, Olson y Barth. Esto no quiere decir necesariamente que la obra quede coja en ciertos planos, pero tampoco ayuda a suplir el ya tradicional olvido crítico, cuando no descuido consciente, hacia determinados autores (Anderson, como ejemplo paradigmático). Por otra parte, este desequilibrio entre unos autores y otros lleva en ocasiones a resumir casi de un plumazo la obra de determinados literatos. Poe, Anderson, Duncan y Ashbery -entre otros- cuentan con una página escasa cada uno. Djuna Barnes y Robert Creeley, menos afortunados, cuentan con tan sólo dos líneas (una para cada uno; pp. 303 y 272, respectivamente), que no aportan nada sobre sus lugares e importancia dentro de la historia de la literatura norteamericana.

En segundo lugar, nos parece que el tono íntimamente personal e impresionista en que está escrita esta Literatura norteamericana (una inclinación de escritura hoy tan de moda entre numerosos estudiosos e investigadores) puede, sin embargo, resultar excesivamente difícil para el lector común en numerosos momentos. Las peculiarísimas asociaciones intertextuales y psicológicas que se exponen a lo largo de toda la obra, y que sin duda confieren una amplitud y riqueza inusuales en los estudios literarios, pueden al mismo tiempo ser un obstáculo en la comprensión del texto.

Ricardo Miguel Alfonso

Michael S. Rochemont and Peter W. Culicover. English Focus Constructions and the Theory of Grammar. Cambridge Studies in Linguistics. Cambridge: Cambridge University Press, 1990, pp. VII +210 .

When one comes across any title written by either Rochemont or Culicover, or by both, one feels that the product is likely to be brilliant. If, in addition, the series to which the volume under discussion belongs is the Cambridge Studies in Linguistics, that surmise amounts to almost complete certainty. This time Rochemont (University of British Columbia) and Culicover (The Ohio State University) explore the possibility of treating 
some constructions that traditionally have been labelled 'stylistic' as purely syntactic devices that the theory of grammar must incorporate. Their framework is Transformational Generative Grammar, more specifically Government and Binding Theory, with which every reader of the book must be conversant.

Let us first of all put forward the four types of construction with which the book is concerned:

(1) a. Extraposition (EX) from the subject (SX): A man came into the room with blond hair.

b. EX from the object (OX): Mary was talking to a man at the party that she went to school with.

c. Extraposed so-result clauses (RX): So many people came to the party that we left.

d. Phrase-level comparative EX: More people came to the party than John invited.

e. Sentence-level comparative EX: More people came to the party than I expected.

(2) a. Directional Inversion: Into the room walked John.

b. Locative Inversion: At the head of the table sat Bill.

(3) Preposing around be (PAB): At the entrance to the park was an old statue.

(4) a. Heavy NP Shift (HNPS): John invited to the party his closest friends.

b. Presentational there Insertion (PTI): There walked into the room a tall man with blond hair.

At this point the reader may wonder why a volume entitled English Focus Constructions should fail to examine various other devices also leading to the focusing of constituents, aside from the structures in (1) to (4). I am alluding, in particular, to clefts and pseudo-clefts, left dislocation, topicalization, or even the type of focus attraction shown by items such as even, merely, truly, simply, hardly, utterly, virtually, only, just, negators or wh-phrases. In fact the choice of title has not been very fortunate, as the only -but difficult - aim of the authors is to prevent the structures in (1) to (4) from being included in the stylistic component of the grammar, as Rochemont (1978) pretended, and to explain them instead by purely syntactic procedures and compulsory "freezing" with respect to further transformations. ${ }^{1}$

Five chapters follow the introduction: the first containing the versions of the concepts that will be used in the book; chapters 2 to 4 are devoted to EX, Directional/Locative Inversion (D/L) and PAB, HNPS and PTI respectively, and the final chapter deals with questions which affect focus constructions in general. Excellent and comprehensive references to transformational studies and a useful index of names complete the volume.

In Chapter one, we find the X-bar analysis which the authors follow, as well as their "versions" of Move $\alpha$, Subjacency and Empty Category Principle (ECP). The final section of this chapter, entitled "The Theory of Focus," deals with the relationship between focus, stress, c-construability (Rochemont 1976), and the difference between pairs such as, on the one hand, structural and simple, and, on the other, unmarked and contrastive foci.

Chapter 2 is centred on EX. It is the "Complement Principle" that allows Rochemont and Culicover to reach the conclusion that EX is base-generated, i.e., the EX phrase 
appears at D-structure in its actual position, and no operation of Move $\alpha$ is thus needed. $\mathrm{CP}$, which in principle operates in S-structure, states that the extraposed phrase must be a potential complement of the one on which it 'depends' and both have to be in a government relation. As a consequence, the possible locations for SX are either IP or VP, and just VP for OX.

The contents of Chapter 3 are $\mathrm{D} / \mathrm{L}$ and $\mathrm{PAB}$. Both constructions are explained in the same way, as instances of a certain type of topicalization.

HNPS and PTI are dealt with together in Chapter 4, both considered as cases of rightward Move $\alpha$, the former to a position adjoined to VP, the latter to one adjoined to IP, in order to satisfy ECP and Subjacency. As far as PTI is concerned, a further, compulsory, insertion of there is postulated so that the trace resulting from movement can be lexically governed. In HNPS there-insertion is obligatorily absent.

With the goal of the book thus seemingly accomplished, Rochemont and Culicover introduce in Chapter 5 further consideration of the ECP, Subjacency and other scholars' proposals for PTI or D/L, which in my opinion should not be there. The Focus Effect, already commented upon in Chapter 1 , is seen as a consequence of the syntactic configurations shown in Chapters 2, 3 and 4, that is, of EX, D/L, PAB, HNPS and PTI. These structures interact "with a principle of UG [Universal Grammar] from which it follows that these constructions must exhibit the FE [Focus Effect] with respect to a specific phrase" (p. 149). In other words, the theory of grammar will mark as focal extraposed phrases, topicalized segments in $\mathrm{D} / \mathrm{L}$ and $\mathrm{PAB}$, or the rightwards moved constituent in HNPS and PTI. This, in my view, is doubtlessly the weakest proposal in the volume. Despite the fact that Rochemont and Culicover's is not a functional framework, it is not coherent to assert that after the operation of certain syntactic devices, some segment within the utterance is focused, i.e. not c-construable. On the contrary, I think that somewhere in D-structure a constituent is marked as focal and thus it requires transformations or special base-ordering so that it will be overtly marked as communicatively focused. I do not in the least deny the syntactic character of the derivation of, say, focal procedures from $D$-structure to actual speech, which makes Rochemont and Culicover's study a compulsory source of research.

\section{Note}

1. Two main reasons had been argued to the fact that EX, Directional/Locative Inversion (D/L), PAB, HNPS or PTI had to be explained by stylistic rules: (i) these rules just apply to Sstructures, blocking for instance $w h$-movement after EX: "** What colour hair did a man walk into the room with?" and (ii) there are no differences as far as truth-conditions are concerned, but just differences of focus. See Culicover (1980) and Guéron (1980) for counter-examples to the aforementioned claim.

\section{Other Works Cited}

Culicover, P. W. “Adverbials and Stylistic Inversion.” Social Science Working Papers 77. Irvine: University of California, 1978. 
Guéron, J. "On the Syntax and Semantics of PP-Extraposition." Linguistic Inquiry, 11 (1980), 637-678.

Rochemont, M. S. A Theory of Stylistic Rules in English. New York: Garland Press, 1978. . Focus in Generative Grammar. Amsterdam: John Benjamins, 1976.

Javier Pérez Guerra 